\title{
A influência pictórica sobre a concepção dos cartes de visite fotográficos oi- tocentistas
}

\section{The pictoric influence in the conception of cartes de visite}

\author{
Luiz Henrique Vieira \\ Universidade Federal de Minas Gerais \\ luizhvieira1@gmail.com
}

Resumo: Este artigo pretende discutir e contextualizar, historicamente, a posição de Benjamin, em sua "Pequena história da fotografia", sobre os retratos fotográficos produzidos na segunda metade do século XIX; assim como demonstrar, a partir de pesquisa iconográfica e através dos métodos analítico e comparativo, as evidentes influências da retratística pictórica clássica sobre a concepção desses retratos, considerando elementos compositivos de valor simbólico e o clima de teatralidade, recorrentes em ambas as práticas. Tais influências, já mencionadas por outros autores, são ainda carentes de demonstrações minuciosas. Para isso, foram escolhidas obras da retratística majestática e principesca, como cânones imagéticos que teriam sido tomados como referenciais em determinados retratos fotográficos oitocentistas.

Palavras-chave: retrato; fotografia; carte-de-visite; século XIX; Benjamin.

\begin{abstract}
Benjamin's position on his "Little History of Photography" about the photographic portraiture produced on the second half of the XIX century. It also aims to make evident, from the iconographic research and the analytical and comparative methods, the classic pictography influence in the conception of these portraits, taking into consideration the composition elements of symbolic value and the theatrical environment that occur in both practices. Such influence, already mentioned by previous authors, still lack further investigation. Thus, this article chose to present majestic and princely portrait works, as imagery aphorisms that may have become the reference of certain 1900's photographic portraits.
\end{abstract}

Keywords: portrait, photography, carte-de-visite, XIX century, Benjamin. 


\section{A definição do objeto de estudo}

Quando, há alguns anos, tive a oportunidade de ler a "Pequena história da fotografia", do aclamado Benjamin (1994), fui tomado por um incômodo sobre a forma com que ele estabelece um juízo de gosto para diferenciar o que denomina de período áureo da fotografia (segundo ele, "durante o primeiro decênio da nova descoberta"1), da produção do "período de declínio [...] quando o gosto experimentou uma brusca decadência" (1994, p. 99). Enfim, Benjamin denigre a produção "comercial" pós Disdéri ${ }^{2}$, alegando intenções puramente financeiras, por parte dos fotógrafos e tecendo comentários, como o seguinte:

Foi nessa época que começaram a surgir os primeiros álbuns fotográficos. Eles podiam ser encontrados nos lugares mais glaciais da casa, em consoles ou guérridons, na sala de visitas - grandes volumes encadernados em couro, com horríveis fechos de metal, e as páginas com margens douradas, com a espessura de um dedo, nas quais apareciam figuras grotescamente vestidas ou cobertas de renda [...] (1994, p. 97).

Como em outros momentos do texto, o autor, na minha opinião, se mostra precipitado, em seu juízo de gosto, e comete uma generalização categórica, em um depoimento reducionista; descartando os inúmeros retratos magníficos produzidos, dentro do formato carte de visite e seu primo - o cabinet card ${ }^{3}$, além dos ambrótipos, ferrótipos e calótipos. É importante considerar, que o comentário inflamado de Benjamin é datado de 1931, no apogeu do modernismo - movimento eminentemente reativo aos modelos clássicos de representação -, após as ações das vanguardas artísticas do início do século, que pretendiam romper com todos os vestígios de tradição e alcançar a especificidade dos mediuns de expressão. Ou seja, em 1931, o cenário artístico já havia assistido a movimentos como o Dadaísmo, o Fovismo, o Futurismo e o Cubismo, e havia sete anos, tinha sido publicado o Manifesto Surrealista - movimento pelo qual Benjamin se interessa, tendo inclusive publicado o ensaio "O surrealismo: o último instantâneo da inteligência europeia". Também é necessário salientar a adesão do autor aos fundamentos comunistas propostos por Karl Marx - o que deve ter contribuído para sua recepção

\footnotetext{
${ }^{1}$ Neste trecho ele comete um equívoco, nomeando fotógrafos que teriam produzido neste período. Entre eles, ele cita a importante Julia Margaret Cameron que, na realidade, só começa a fotografar em 1863, aos 48 anos.

${ }^{2}$ Fotógrafo que patenteou o formato carte de visite, em 1854.

${ }^{3}$ Os cartes de visite costumam medir em torno de $11 \times 7 \mathrm{~cm}$ e os cabinet cards, aproximadamente, $16 \times 10 \mathrm{~cm}$.
} 
do que ele denomina de "decadente", visto que tal objeto estava impregnado, na sua visão, de valores relacionados à "degenerescência da burguesia imperialista" (1994, p. 99).

Deixo claro, aqui, que o meu objetivo não é defender uma tese contra o texto de Benjamin $^{4}$ - apenas, quis relatar a minha reação diante de seu texto; reação essa que, possivelmente, me levou a realizar uma pesquisa iconográfica sobre a produção de retratos oitocentistas.

Hoje, afastados dos paradigmas reativos modernistas, há aproximadamente meio século, já é possível olhar para a arte do passado sob uma nova perspectiva e com liberdade para, inclusive, referenciá-lo. Por outro lado, atualmente, assistimos a um crescente e notório interesse por questões relacionadas à memória, sendo que um dos autores mais discutidos, estudados e citados tem sido o alemão Aby Warburg ${ }^{5}$ (1866-1929), e na academia cresce o número de disciplinas que discutem a memória sob diversos viéses. O livro de Andreas Huyssen, Seduzidos pela memória, aponta "o surpreendente nascimento de uma cultura e de uma política de memória, e sua expansão global a partir da queda do Muro de Berlim, do fim das ditaduras latino-americanas e do apartheid na África do Sul”. . Ou seja, é mais que oportuno que, neste momento, se lance um novo olhar para a produção dos cartões fotográficos oitocentistas.

Como o próprio Benjamin (1994) comenta, nos primórdios da fotografia, foram muitos os pintores que migraram, provisória ou definitivamente, para a o novo ofício. A rigor, esses novos artistas-fotógrafos, instrumentalizados pelo conhecimento e pela sensibilidade desenvolvida pela prévia experiência estética, se mostravam mais aptos a compor retratos mais elaborados e, possivelmente, terão produzido obras esteticamente mais relevantes que os não habilitados. Ferreira de Andrade (2004) verifica que, diferentemente do que ocorreu na Europa, esta migração não ocorreu em igual proporção nos Estados Unidos, e a maior parte dos primeiros fotógrafos veio de áreas não relacionadas com as artes plásticas. Em sua Educação sentimental, Flaubert (2006), declarado inimigo do retrato fotográfico, comenta, com certa dose de desprezo, a instabilidade e indefinição profissional de seu personagem, que o levou

\footnotetext{
${ }^{4}$ Talvez, para Benjamin, esse tipo de retrato, que, na época poderia parecer antiquado ou associado a um tipo de arte, tinha sido questionada pelo modernismo.

${ }^{5}$ O respeitado Didi-Huberman lançou, em 2002, o ensaio A imagem sobrevivente: História da arte e tempo dos fantasmas segundo Aby Warburg.

${ }^{6}$ Resenha publicada na orelha do livro. HUYSSEN, Andreas. Seduzidos Pela Memória. Rio: Aeroplano, 2a ed., 2004.
} 
ao ofício de fotógrafo: "Pelegrin, depois de ter andado no fourierismo, na homeopatia, nas mesas giratórias, na arte gótica e na pintura humanitária, fizera-se fotógrafo" (2006, p. 419). Apesar da ironia do autor, de fato, houve muitos que migraram de áreas não relacionadas às artes visuais. De qualquer forma, a infinidade de retratistas não nos facilita (e talvez, nem interesse a esta pesquisa; pelo menos, neste momento) identificar aqueles que migraram das artes plásticas; no entanto, há nomes importantes, como o do escocês David Octavius Hill importante pioneiro da retratística fotográfica. Pintor escocês, Hill associou-se a Robert Adamson, com quem produziu uma das mais importantes e aplaudidas obras fotográficas do século XIX, tendo como foco, justamente, o retrato. Por outro lado, ainda citando retratistas celebres, há o caso do inglês Henry Peach Robinson, pintor de formação acadêmica, que também migrou para a fotografia em 1852, quando abre seu estúdio e começa a produzir retratos bastante elaborados.

Em minhas investigações, tenho observado que, salvo exceções, cada década do período vitoriano determina certos padrões compositivos, repertório de poses, possibilidades e limitações técnicas, tipo de vestuário e intenções específicas que vão caracterizar a produção de retratos fotográficos do respectivo período.

Entre os vários formatos de retratos fotográficos, praticados no séc. XIX, os que mais me entusiasmam e intrigam, a ponto de querer me debruçar sobre eles, são justamente o carte de visite (ou CVD, abreviatura que passarei a adotar neste texto) e o cabinet card (CC) - tão marginalizados, quanto fascinantes e ricos em informações sobre os ideais sociais inerentes àquele período. Desta forma, fica definido o objeto central deste artigo.

O CVD é patenteado, em 1854, pelo francês André Adolphe Disdéri e, na década seguinte, já havia se tornado um objeto de troca indispensável nas relações sociais, em centros urbanos dos quatro continentes. Um carte de visite típico implica uma impressão fotográfica em papel albuminado ${ }^{7}$ de gramatura levíssima, colado sobre um cartão relativamente resistente, sobre o qual eram previamente impressas, de forma mais ou menos ornamental, informações sobre o estúdio fotográfico (nome, logo, endereço e, muitas vezes, referências sobre a disponibilidade do negativo para futuras cópias) - dados que, além de constituir uma assinatu-

\footnotetext{
${ }^{7} \mathrm{Na}$ grande maioria dos casos, usou-se o papel albuminado; em uma minoria foram empregados processos como a gelatina de prata e a platinotipia.
} 
ra, denotam uma clara estratégia publicitária. Essas marcas costumavam figurar abaixo da fotografia ou, de forma mais chamativa, no verso do cartão; no entanto, há exemplares, como o da FIG. 1, em que esta informação é encontrada na frente e no verso.

West (2004, p.189) observa uma característica incontornável, inerente a grande parte da produção desses retratos: "[...] desde o inicio, fotógrafos retratistas passaram a adotar poses e convenções próprias de retratos pictóricos." A autora não chega a especificar o estilo das pinturas usadas como modelo; de qualquer forma, se observarmos, atentamente, as soluções empregadas por grande parte dos fotógrafos oitocentistas, podemos estabelecer uma relação explícita entre os retratos produzidos por eles e os de estilo Barroco e Rococó, pintados nos dois séculos anteriores. Não que estes dois estilos tenham sido os únicos referenciais.
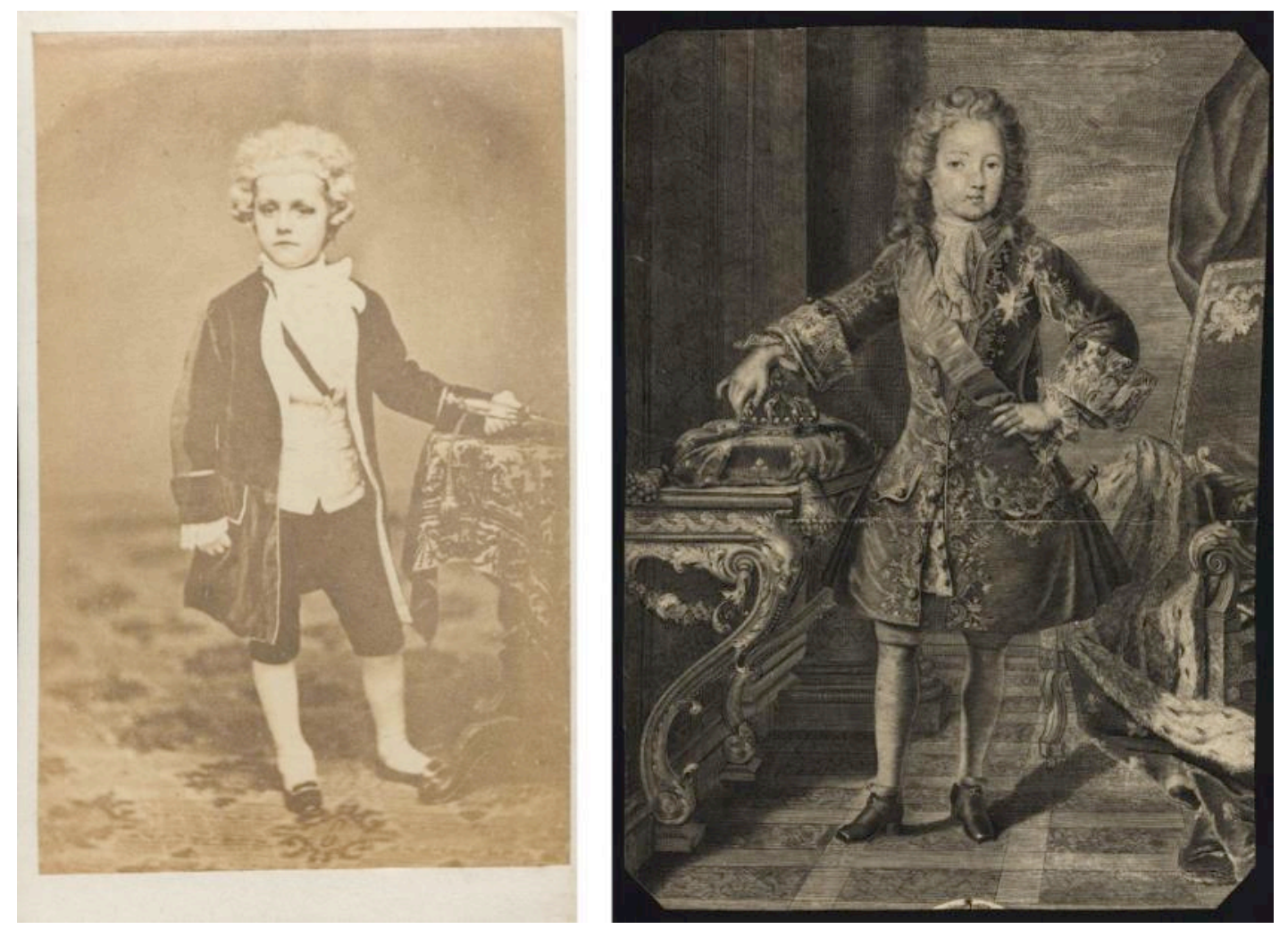

Figura 1: (esquerda) Montgomery P. Simons. Retrato de Persifor Frazer. Carte de visite produzido a partir de um daguerreótipo de autoria de Marcus A. Root. Philadelphia, ca. $1857^{8}$. (direita) S.l. s.n.. Luis XV, água-forte $\mathrm{p} \& \mathrm{~b}, 39 \times 28 \mathrm{~cm}, 1715(?)^{9}$

\begin{tabular}{lllll}
\hline 8 & Coleção & Library & Company of Philadelphia fonte da & imagem: \\
http://www.librarycompany.org/catchingashadow/section5/index.htm; acesso em: 14 set. 2015. &
\end{tabular}

eISSN: 2179-8478 
Evidentemente, por não disporem de recursos luminotécnicos $\operatorname{artificiais}^{10}$, a iluminação desses retratos costumava ser limitada e precariamente trabalhada e, dessa forma, não podemos buscar uma relação entre ela e as formas de iluminação observada em retratos pictóricos setecentistas. No entanto, elementos como colunas, cortinados, mesas e cadeiras de apoio, paisagens de fundo, etc. constituem um legado pictórico que foi, amplamente, utilizado nos cartões fotográficos oitocentistas. Eventualmente, como podemos conferir na FIG. 1, a necessidade de referenciar a pintura era tamanha que alguns modelos chegavam a posar com trajes característicos do século anterior, como na FIG. 1 (esquerda) que, apesar de tratar-se de uma calcografia ${ }^{11}$, está em pleno acordo com os cânones de representação do retrato pictórico.

A referênciação à pintura não ocorria de forma inconsciente e velada, já que manuais de fotografia oitocentistas, como o The Year Book of Photography and Amateurs Guide, publicado em Londres entre 1870 e 1879, recomendavam que o fotógrafo se familiarizasse com os princípios deixados pelos grandes mestres. O editor do manual, Simpson (1879, p. 104) apud Koutsoukos (2008, p. 56), observou

[...] que não havia dúvida de que a parte mais difícil da fotografia era o retratismo, já que, para o retrato, o fotógrafo deveria prestar atenção em muitas coisas ao mesmo tempo. Todavia, se ele estivesse familiarizado com os "princípios" deixados pelos velhos mestres, havia grande chance de que conseguisse fazer um trabalho correto.

De acordo com a proposta teórico-metodológica de Ricoeur (2007, p. 188), que afirma que "é armado de perguntas que o historiador se engaja em uma investigação de arquivos", defino a hipótese a ser defendida neste estudo. Considerando que é amplamente comen$\operatorname{tada}^{12}$ a herança de códigos de representação consagrados pelos retratos pictóricos na concep-

\footnotetext{
${ }^{9}$ Coleção Biblioteca Nacional de Portugal. Fonte da imagem: fonte da imagem: http://purl.pt/6172; acesso em: 11 ago. 2015.

${ }^{10}$ Desconsiderando os experimentos anteriores, o primeiro flash fotográfico, aprovado a adotado pelos profissionais, é desenvolvido por Adolf Miethe e Johannes Gaedicke, em 1887.

${ }^{11}$ Calcografia: gravura em metal. Nessa época, era comum algumas gravuras serem baseadas em pinturas, as chamadas "gravuras de reprodução". Isso explica sua semelhança com os retratos pictóricos. Isso se devia à uma vontade dos colecionadores de registrar essas pinturas, antes do advento da fotografia, quando não havia outros meios para isso.

${ }^{12}$ Além da já citada West (2004, p.189), também o defende, por exemplo, Fabris (2004, p. 32).
} 
ção dos retratos fotográficos oitocentistas, sem, no entanto, ser realizada uma análise comparativa desses dois mediums, me proponho a empenhar-me nessa demonstração, discutindo-a.

Como se sabe, o legado de retratos pictóricos produzidos nos séculos XVII e XVIII é vastíssimo. Poderíamos abranger um campo de pesquisa mais amplo, incluindo os retratos aristocráticos, os burgueses e os chamados 'oficiais' - aqueles destinados a representar, publicamente, personagens de relevância política; no entanto, nada parece mais justo que delimitar o campo de observação aos retratos que, provavelmente, terão servido de referência formal e ideológica às representações dos demais indivíduos - os retratos dos monarcas e dos príncipes. Entretanto, apesar de essa influência ser notória em vários retratos usados em cartões fotográficos, há de se ter cuidado com as generalizações e pontuar a existência de outros padrões que se distanciam do referencial posto em questão. Apesar de não ser comentado ${ }^{13}$, também se faz necessário observar a influência dos retratos gráficos (desenhos ou calcografias) sobre determinado tipo de cartão fotográfico. Apesar de não ser meu foco, aqui neste artigo, começo exemplificando justamente esta ocorrência.

\footnotetext{
${ }^{13} \mathrm{Em}$ minha pesquisa, até agora, nenhum dos autores que consultei chegou a mencionar tal influência.
} 

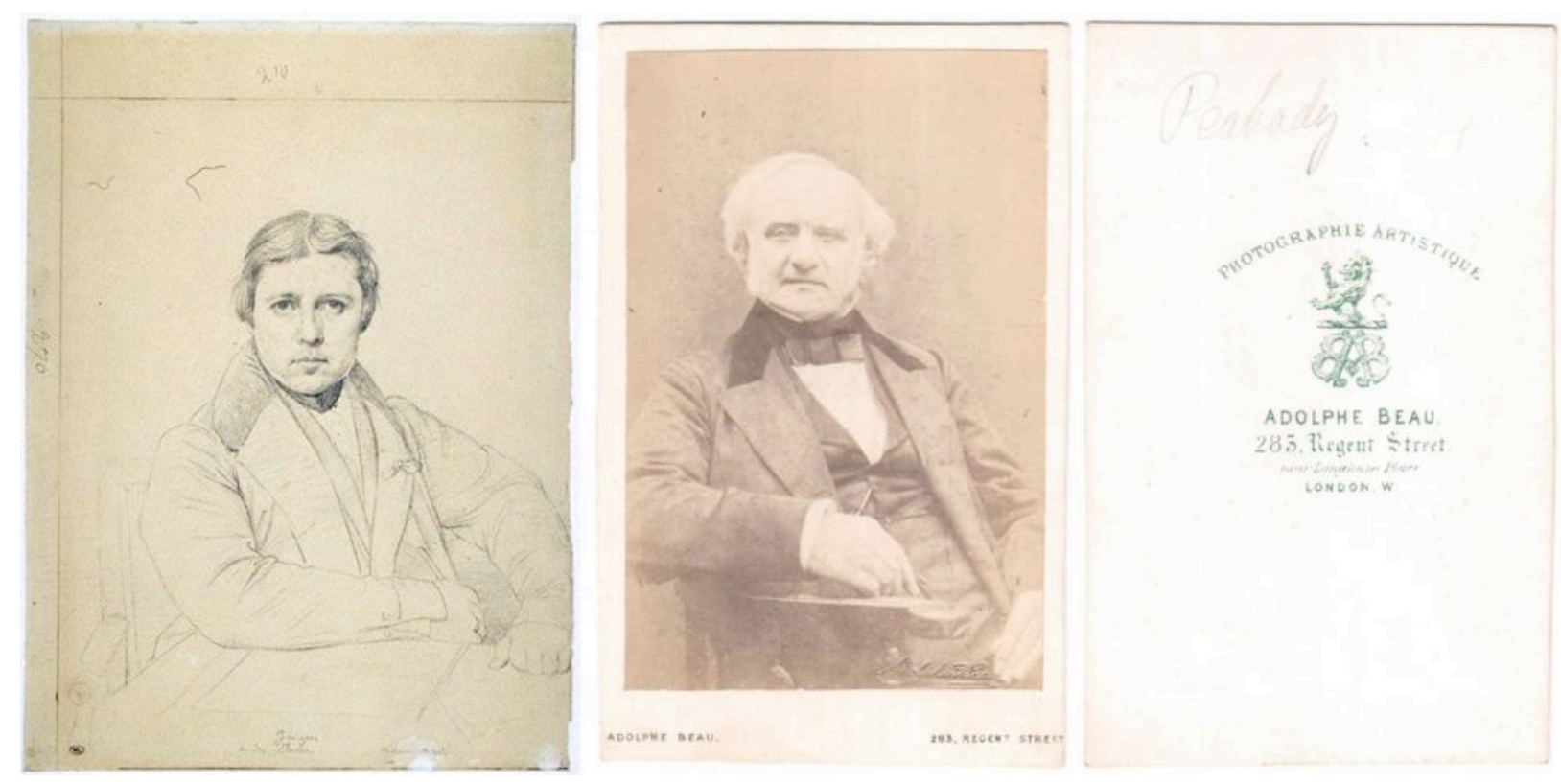

Figura 2: (esquerda) Jean-Auguste-Dominique Ingres. Autoportrait, à mi-corps, 29,9 x $21,9 \mathrm{~cm}, 1835^{14}$. (direita) Adolphe Beau. Frente e verso de Carte de visite de homem não identificado, c. 1860 (data estimada) $)^{15}$

O autorretrato de Ingres (FIG. 2, esquerda), realizado dois anos antes de o daguerreótipo ter sido oficialmente apresentado à sociedade, é, certamente, um estudo para uma pintura ou uma calcografia. Neste desenho, o artista se representa sentado a uma mesa de trabalho, diante de uma folha de papel, sendo que uma das mãos está apoiada sobre a mesa e a outra, segurando um lápis. Dessa forma, se configura uma autorrepresentação como artista. Abstraindo-se dos dois elementos que caracterizam o ofício do autor (mas que também poderiam ser usados para identificar um escritor), tem-se uma fórmula composicional, largamente empregada na produção dos daguerreótipos e, inclusive, de determinada categoria de CVDs, como no exemplo dado na FIG. 2 (direita). Talvez, seja importante frisar que os dois trabalhos foram realizados com a diferença de, aproximadamente, 25 anos - podendo, em minha opnião, ser considerados contemporâneos.

\footnotetext{
${ }^{14}$ Acervo Museu do Louvre. Photo (C) RMN-Grand Palais (musée du Louvre) / Thierry Le Mage. Fonte da imagem: http://www.photo.rmn.fr/archive/03-010622-2C6NU04D6UJP.html; acesso em: 16 set 2015.

${ }^{15}$ Coleção XXXXX.
} 

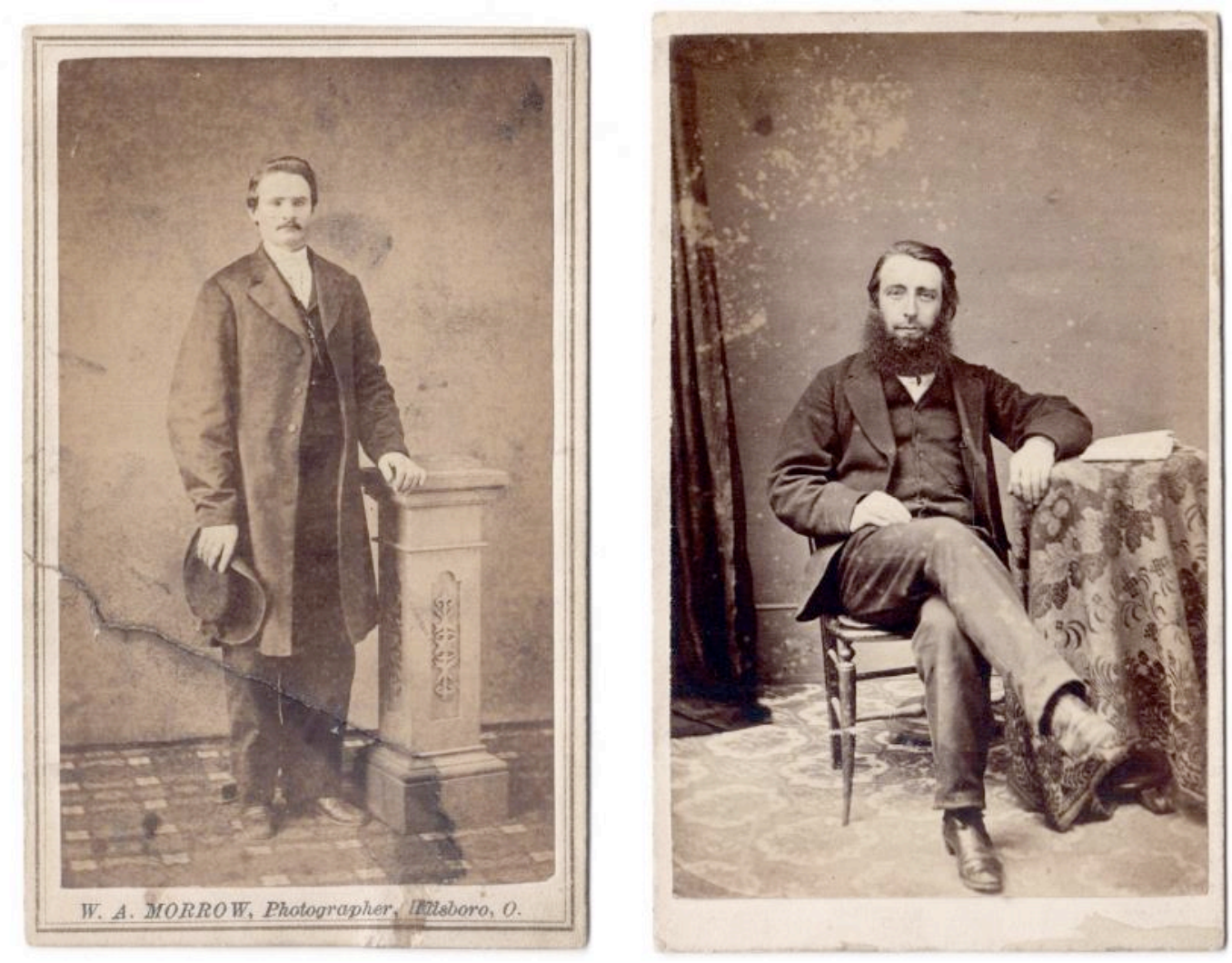

Figura 3: (à esquerda) W. A. Morrow. Carte de visite de homem não identificado, Hillsboro, EUA, c. 1870. (à direita) H. Mossis Artist. Carte de visite de Joseph Watkins Gray, Suíça, c. 1860 (ambas as datas estimadas) ${ }^{16}$.

"[...] A carte de visite geralmente compreende a figura toda, ou sentada ou em pé, graciosamente apoiada em contra uma coluna ou balaustrada" (Towler apud Mendes, 1998, p. 115). Aqui, o autor descreve, em 1864, uma das fórmulas aplicadas na elaboração de cartes de visite, mas faz parecer que este era o único padrão usado, ou, pelo menos o usado na grande maioria desses cartões - o que não coincide com minha observação. Penso que, além das duas fórmulas (FIG. 3) mencionadas por Towler, podemos apontar algumas outras bastante recorrentes.

O primeiro dos três CVDs (FIG. 4) retrata, em plano americano, um menino. A imagem recebeu tratamento de retoque, de acordo com soluções típicas de um desenho clássico, em que a figura é diluída no fundo branco do papel. Esta foi uma das estratégias

\footnotetext{
${ }^{16}$ Os dois CVDs integram a Coleção XXXXX.
} 
usadas, na segunda metade do séc. XIX e nos primeiros anos do séc. XX, para aproximar a fotografia da linguagem específica do desenho.
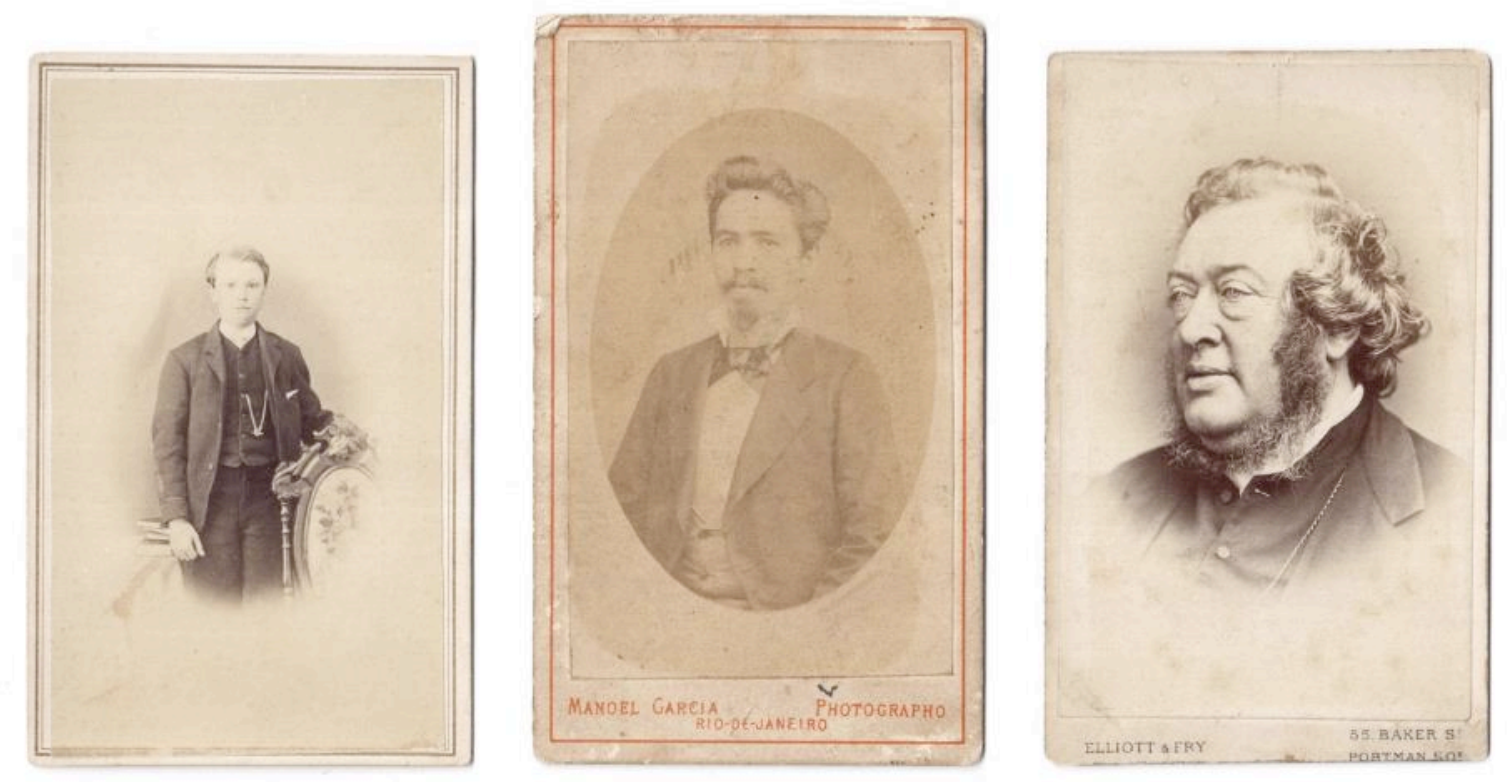

Figura 4: (esquerda) S.l. s.n.. Carte de visite de jovem não identificado, s/ data. (centro) Manoel Garcia. Carte de visite de Américo Pinto, Rio de janeiro, c. 1870. (direita) Elliott \&Fry. Carte de visite de homen não identificado, Londres, c. $1865 .^{17}$ (datas estimadas)

O CVD assinado por Manoel Garcia (FIG. 4 - centro) apresenta um retrato em forma ovalada (largamente usada na retratística clássica), representando o busto completo (até a cintura) de Américo Pinto. Este formato de retrato é muito característico de cartes de visite dos anos 1870 , sendo que são encontrados exemplares dessa natureza, produzidos no Brasil, até a década seguinte.

O CVD assinado por Elliott \& Fry (FIG. 4 - direita) apresenta uma representação do busto de um homem (um clérigo?), com ênfase na cabeça, sendo que, na altura da metade do tórax, a figura começa a se diluir no fundo claro do papel. O importante estúdio responsável pela execução desse retrato foi fundado, em 1863, por Joseph John Elliott e Clarence Edmund Fry. Inicialmente localizado na Baker Street, 55, onde permaneceu até 1886, o estúdio teve outras sedes posteriores e foi fechado em 1963. No início da década de 1940, grande parte do

\footnotetext{
${ }^{17}$ Os três CVDs integram a coleção XXXXX.
} 
acervo de negativos produzidos pela empresa foi destruída em um incêndio, e os que restaram encontram-se na National Portrait Gallery, em Londres. Interessante constatar que a grande maioria dos retratos pertencentes a essa instituição, é constituída representações de busto, como o exemplar mostrado neste texto ${ }^{18}$.

Dessa forma, fica esclarecido que a representação de corpo inteiro (sentado ou de pé) foi apenas uma das soluções aplicadas em retratos usados na composição de CDVs.

\section{Relações entre a retratística majestática e principesca e os cartes de visite oitocentistas}

\subsection{O primeiro, mas não o mais relevante dos referenciais, aqui mencionados}

Não serão comentados os retratos de Henrique IV - ou O Bom Rei Henrique, como era chamado - e nem os de seus antecessores, considerando que há de se criar um recorte sucinto a ser estudado; mesmo porque o campo temporal de observação foi delimitado entre os séculos XVII e XVIII. Assim sendo, a primeira obra a ser observada é o retrato de Luís XIII, realizado na escola de Philippe de Champaigne, em 1647.

\footnotetext{
${ }^{18}$ Fonte da informação: texto sem assinatura, publicado no site da National Portrait Gallery. Disponível em: http://www.npg.org.uk/collections/search/person/mp06938/elliott--fry?search=sas\&sText=Elliott+\%26+Fry ; acesso em: 16 set. 2015.
} 


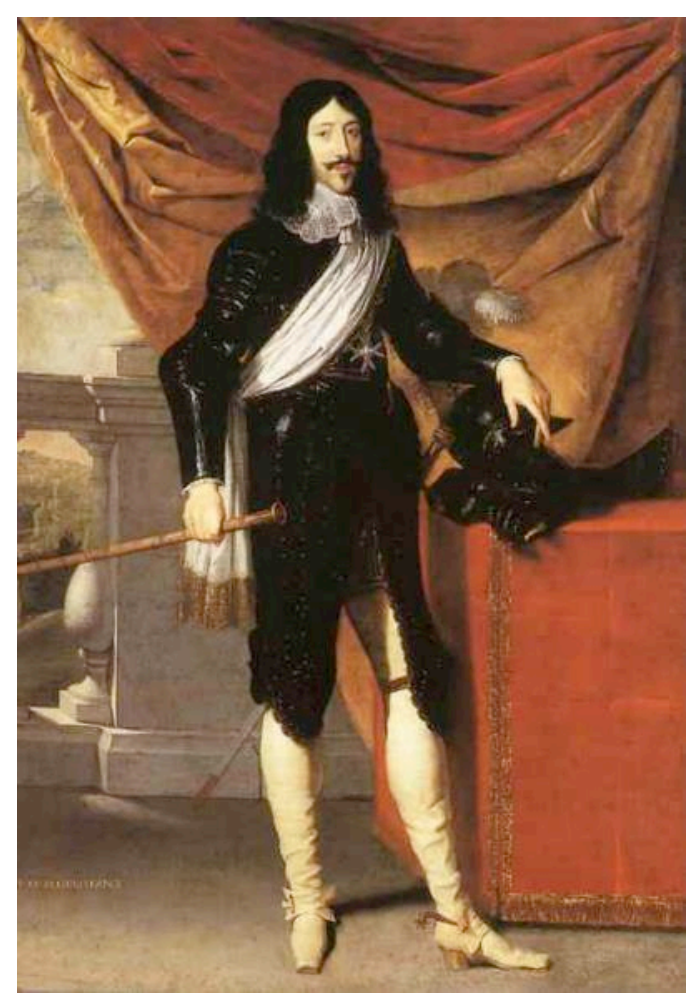

Figura 5: Escola de Philippe de Champaigne. Retrato póstumo de Luís XIII, dimensão(?), 1647. ${ }^{19}$

Há outro retrato datado de 1622-39 e de autoria do mesmo artista, em que o monarca é representado em traje de coroação e aparenta maior majestade; no entanto, a escolha deste (FIG. 5), em que ele é representado em traje de cavalaria, releva um padrão formal que é de maior interesse à esta pesquisa, considerando que a pintura reúne vários elementos cênicos usados na produção dos cartões fotográficos: a cortina drapeada, a balaustrada, o apoio para a mão (pode tanto ser uma pequena mesa, como uma cadeira ou uma coluna) e a paisagem (representada, nas fotografias, pelos painéis pintados e usados como fundo).

Em seu retrato (FIG. 5), Luís XIII se apresenta de pé e de frente para o espectador, com o corpo ligeiramente voltado para a direita. Ele está vestido como um cavaleiro da Ordem do Espírito Santo, com uma das mãos apoiadas sobre o capacete colocado sobre uma

\footnotetext{
${ }^{19}$ Fonte da imagem: https://commons.wikimedia.org/wiki/File:Louis_XIIIval_grace.jpg. Dados sobre a pintura: http://fr.academic.ru/dic.nsf/frwiki/1078449; acesso em: 12 set. 2015. Tendo buscado este retrato em vários museus e não tendo encontrado, me ocorre que ele possa pertencer a alguma coleção particular. Infelizmente, não encontrei a imagem em boa resolução para impressão.
} 
bancada, ao lado esquerdo do retratado. A outra mão (a direita) segura o bastão. Cruzando seu tronco, uma faixa branca adornada, nas duas extremidades, com franja dourada; abaixo dela, a cruz da Ordem dos Cavaleiros do Espírito Santo ${ }^{20}$. Sobre a bancada, no lugar onde, normalmente, seria representada a coroa, se vê o capacete emplumado. Entre o corpo do monarca e a balaustrada, em segundo plano, um drapejado em tons de terra e vermelho atravessa, horizontalmente, o espaço de representação, enfatizando o caráter teatral do retrato. Em terceiro plano, é representada uma balaustrada, marcando um limite entre o ambiente da pose e a paisagem de fundo. A figura - muito rígida - denuncia a inexperiência do artista (um aluno de Champaigne?), e a pintura, em sua totalidade, não me parece digna de grandes elogios; no entanto, como já mencionado, ilustra convenções que serão comentadas em vários cartões fotográficos a serem tratados neste texto, sendo que nem sempre são vistos todos os elementos reunidos em um único retrato.

Para Burke (2004, p. 34), "algumas dessas convenções sobreviveram e foram democratizadas na era do retrato de estúdio fotográfico, a partir de meados do século XIX". O autor defende que a utilização desses recursos estabelecidos teria sido uma forma de se camuflar as diferenças entre classes sociais. Os fotógrafos teriam oferecido aos clientes o que foi chamado de "imunidade temporária em relação à realidade" (Hirsch apud Burke, ibidem). De acordo com o autor

Sejam eles pintados ou fotografados, os retratos registram não tanto a realidade social, mas ilusões sociais, não a vida comum, mas performances especiais. Porém, exatamente por essa razão, eles fornecem evidência inestimável a qualquer um que se interesse pela história de esperanças, valores e mentalidades sempre em mutação. (ibdem, p. 35)

\footnotetext{
${ }^{20}$ Ordem de cavalaria subordinada à monarquia francesa, fundada por Henrique III, em 1578.
} 


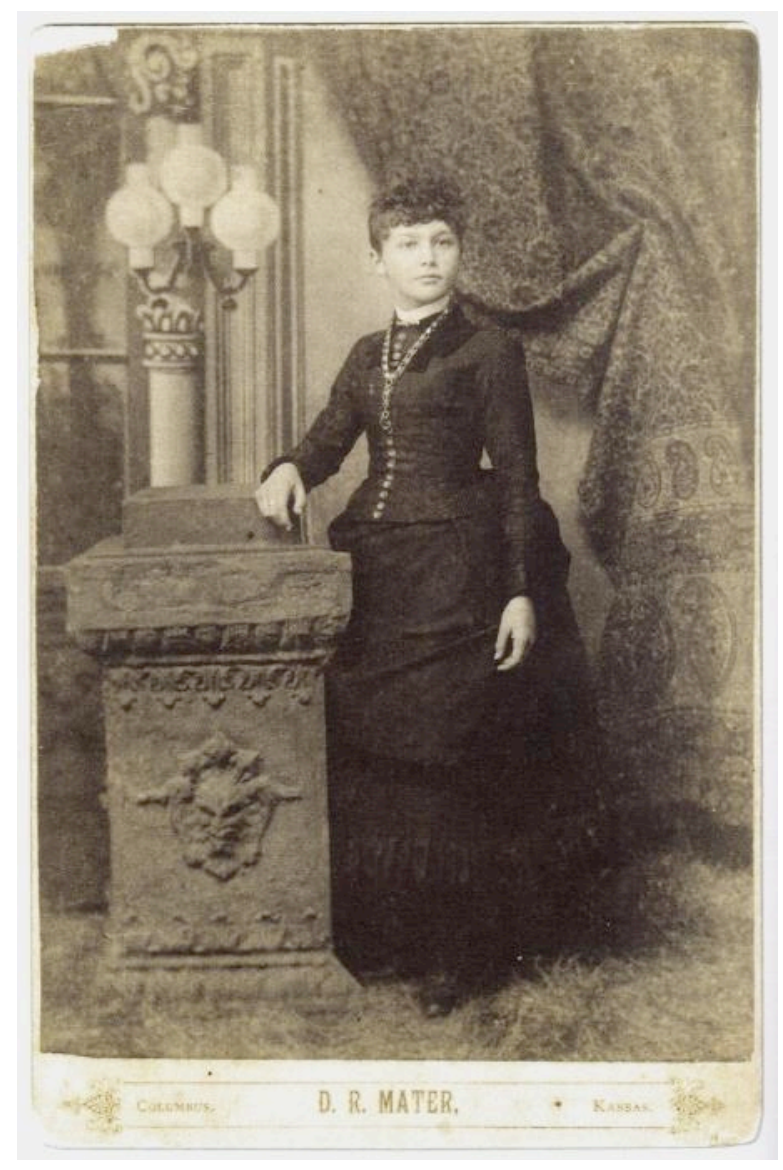

Figura 6: Estúdio D R Mater. CC de jovem senhora não identificada, EUA, $1887^{21}$

A FIG. 6 é um exemplar, um tanto incomum, em que foi feita a opção por se reunir toda a sorte de objetos cênicos habitualmente usados na composição dos retratos, aqui analisados. Provavelmente, os únicos elementos que foram dispensados foram a cadeira e a mesinha, mesmo porque elas fariam as vezes do cippus $^{22}$ usado neste retrato. A fotografia, datada de 1887 , representa uma mulher de corpo inteiro, rodeada por objetos cênicos. Em primeiro plano, de corpo inteiro, o modelo, com a mão direita apoiada sobre um cippus, evita olhar diretamente para a câmera e dirige o olhar para a direita ${ }^{23}$ do espectador. De acordo com Mar-

\footnotetext{
${ }^{21}$ Fonte da imagem: Clark (2013).

${ }^{22}$ Base quadrangular de coluna ou pedestal de estátua.

${ }^{23}$ Recurso amplamente recomendado em manuais oitocentistas de fotografia, como no The History and practice of the art of photography, em que o autor sugere que "os olhos devem estar fixos em algum objeto um pouco acima da câmera e deslocado para um lado - mas nunca na direção ou sobre a câmera" (Snelling, 1849, p. 41 apud Mendes 1998, p. 103).
} 
co Elísio Paiva (2015), “o cippus, como monumento cerimonial ${ }^{24}$, estava em uso desde o Egito antigo. Durante o século XIX (época em que foi produzido esse retrato) se repetiam esses costumes como vinculação estilística ao gosto clássico". Assim, podemos inferir que o uso desse objeto no retrato associa a ideia de cultura ao retratado. O chão, sobre o qual a retratada se posiciona, é recoberto por algo que remete à textura de grama. No segundo plano (muito próximo do primeiro), uma cortina de estampa cashmere ${ }^{25}$ drapeada é disposta sobre um painel, em que se vê representados: uma parede ornamentada e finalizada por uma coluna (símbolo de glória e de estabilidade); ao lado desta, uma porta envidraçada, através da qual se vislumbra um jardim (símbolo do refúgio sagrado e do $\operatorname{cosmo}{ }^{26}$ ); por fim, uma luminária que parece saltar do painel (em efeito 3D), em direção ao modelo. Poderíamos associar esta imagem à ideia de excesso, mas vou optar por não fazer julgamento de gosto.

A FIG. 7 mostra a frente de dois CDVs brasileiros, produzidos entre as décadas de 1860 e 1870. No retrato assinado por Christiano Junior, é representado um jovem rapaz, com traje da década de 1860 , de pé e de frente para o espectador. O braço direito está relaxado ao lado do tronco, e o esquerdo, apoiado sobre uma coluna ornamentada, sobre a qual repousa uma cartola. Atrás no modelo, no chão, é possível distinguir um pano, usado para disfarçar o apoio de corpo $^{27}$. A figura encontra-se isolada de outras informações. O cartão da direita (de autoria não identificada) representa uma mulher, também de pé, com a mão direita apoiada sobre o espaldar de uma imponente cadeira de junco (ou vime), e o outro braço flexionado (em aprox. 150 graus) sustenta a mão (carente do polegar?) que parece estar pressionada con-

\footnotetext{
${ }^{24}$ Amplamente usado na antiguidade para glorificação pública de alguém importante. Eles eram colocados nas ruas, nas vias de entrada das cidades e, era usado também como elemento funerário para memória do morto.

25 “Originalmente uma lã macia feita a partir do pelo de cabras da região de Caxemira na Índia, o termo cashmere passou a ser associado no século 19 à estampa de folhas estilizadas e curvadas que eram aplicadas nos xales e túnicas indianas. As cores predominantes na época eram o preto e o vermelho. Com a descoberta do caminho marítimo para a Índia, os tecidos com estampa cashmere passaram a ser exportados para países europeus principalmente para a Grã-Bretanha". Fonte: http://glossario.usefashion.com/Verbetes.aspx?IdIndice=3\&IdVerbete=607; acesso em: 09 out.2015.

${ }^{26}$ Fonte: http://www.dicionariodesimbolos.com.br/jardim/; acesso em: 09 out. 2015.

${ }^{27}$ Com o propósito de auxiliar na sustentação e imobilização do corpo do modelo, nos primórdios da fotografia, quando o tempo de exposição era longo, foi criado um apoio de corpo, de base pesada e de forma triangular, feito de ferro fundido. Da base, erguia uma haste que sustentava uma espécie de pinça que era ajustada à cabeça do modelo. Este aparelho também recebe o nome de "Brady Stand".
} 
tra o quadril do modelo. O vestido, de talhe muito incomum para o período (não possui a cintura marcada), foi usado sobre a típica crinoline ${ }^{28}$ - tão popular nos anos 1860.

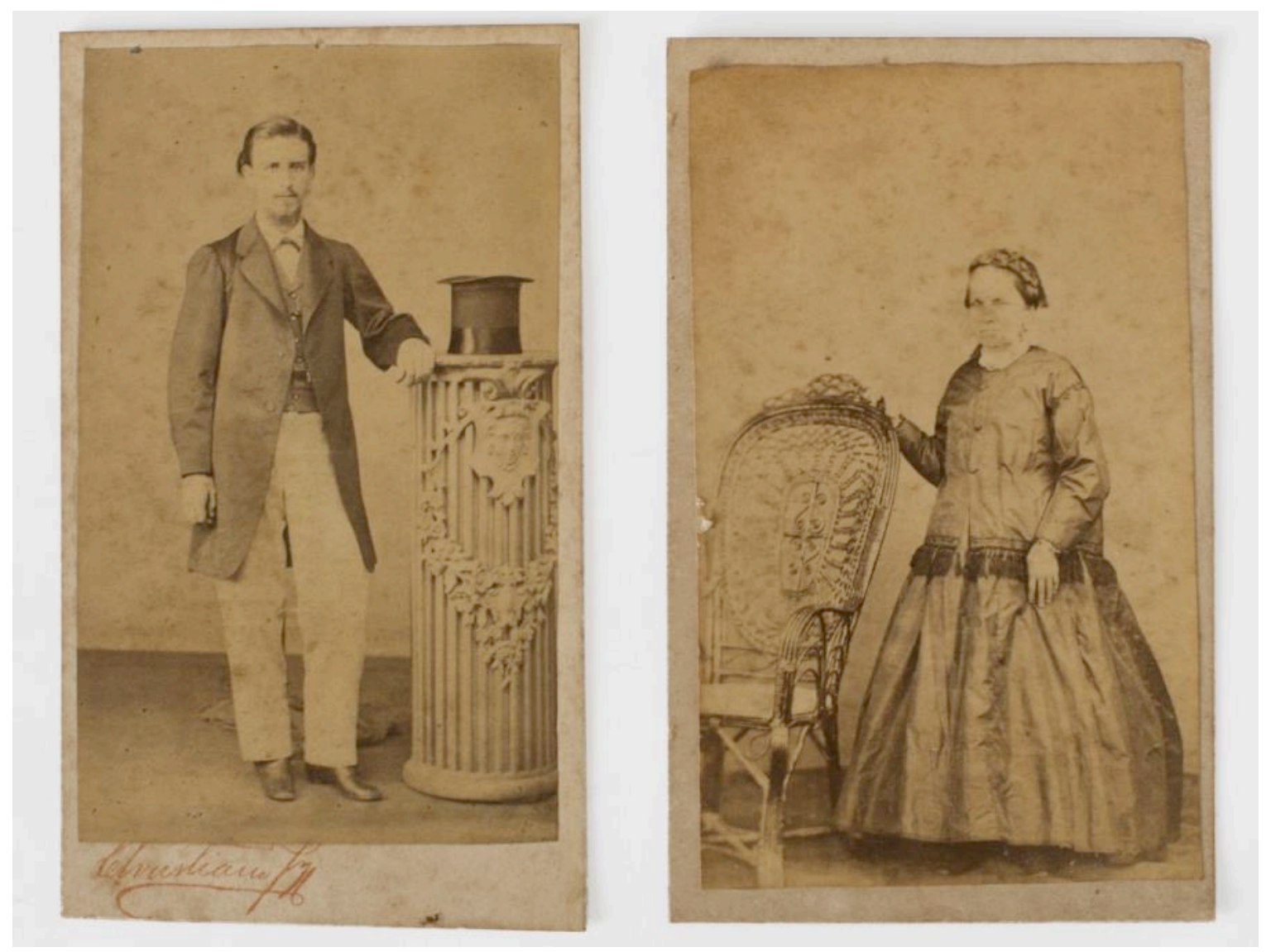

Figura 7: Frente de dois CVDs de modelos não identificados. [esquerda] Christiano Junior (José Christia-

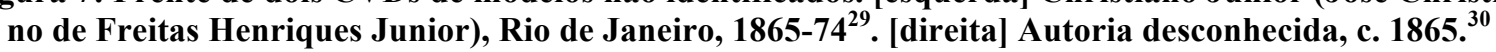

Tanto a coluna, como a cadeira possuem função prática - elas servem de apoio para um dos braços, evitando uma postura monótona do modelo -; além disso, esses objetos constituem presença estetizante dentro da composição. Mas isso não é tudo, visto que os objetos estão carregados de sentido simbólico. Segundo Burke (2004), esses objetos representados junto dos retratados, geralmente, costumam reforçar suas autorrepresentações. Eles "podem

${ }^{28}$ Armação feita de arcos horizontais flexíveis, interligados por fitas, podendo ser confeccionados de diversos materiais - entre eles, a crina que dá origem ao nome do objeto. A crinoline foi, amplamente, usada em meados do século XIX.

${ }^{29}$ No verso do cartão, há indicação do endereço do estúdio: “Rua da Quitanda, 45”. Christiano Junior (como assinava suas fotos) trabalhou nesse endereço entre 1865 e 1874.

${ }^{30}$ Os dois cartões integram o álbum que pertenceu à família de Manoel Vicente Lisboa. Coleção XXXXX. 
ser considerados como 'propriedades' no sentido teatral do termo" (ibidem, p. 32). Sob essa perspectiva, colunas greco-romanas podem ser recebidas como representação da glória de Roma antiga. Por sua vez, cadeiras muito luxuosas podem aludir à ideia de trono, conferindo ao modelo ares aristocráticos.

\subsection{O segundo e o mais relevante dos referenciais, aqui mencionados}

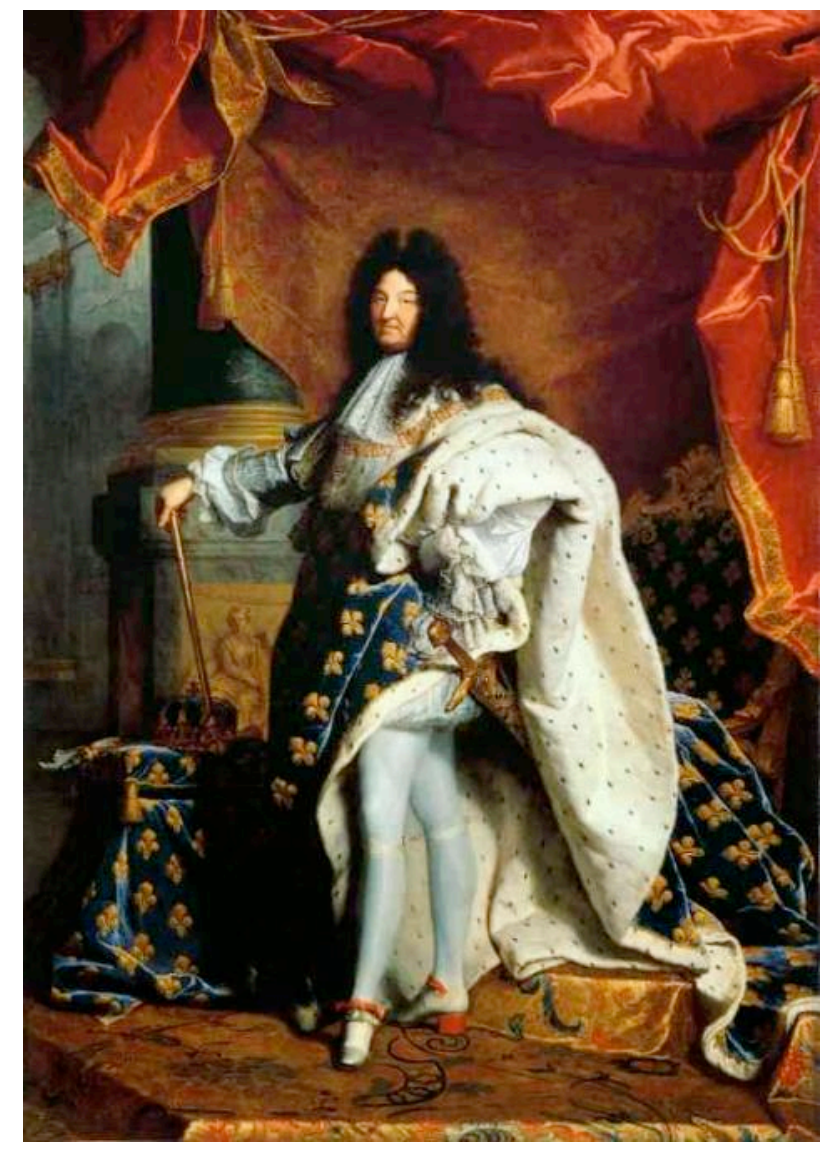

Figura 8: Hyacinthe RIGAUD. Retrado de Louis XIV, óleo s/ tela, 2.77 x 1.94 m, $1701^{31}$.

Reconhecido como grande propagandista e famoso por levar o absolutismo ao seu apogeu, Luís XIV foi objeto de inúmeros retratos que, certamente, ajudaram a consolidar sua imagem soberana. Será comentada, aqui, a mais célebre de suas representações - o retrato (FIG. 8) pintado por Rigaud em 1701, quando o monarca tinha 63 anos de idade. De acordo

\footnotetext{
${ }^{31}$ Collection of Louis XIV, Museu do Louvre.
} 
com Vincent Pomarède ( $\mathrm{sem}$ data $^{32}$ ), em texto publicado no site do Louvre, o retrato foi encomendado para ser presenteado a Felipe V de Espanha, mas, devido ao sucesso que fez junto à corte, a pintura nunca chegou a ser enviada ao monarca espanhol - bisneto de Luís XIV. Para o autor, cada detalhe dessa obra está destinado a produzir a imagem da quintessência do poder absoluto: a nobreza do cenário clássico, a cortina carmesim drapeada, e a solenidade do Rei Sol vestindo seu traje de coroação, rebordado com a flor-de-lis real.

Ele é representado vestindo seus trajes de coroação, a espada real pendendo à altura dos quadris do retratado, logo abaixo da mão que se apoia em sua cintura. A outra mão segura o cetro que está apoiado sobre uma luxuosa banqueta (forrada com o mesmo tecido do manto do monarca), sobre a qual está exibida a coroa e a mão da verdade. Envolvendo dois lados do plano de representação, um voluptuoso panejamento e, logo atrás, dele, do lado esquerdo da composição, vê-se uma sólida e imponente coluna que separa o ambiente de pose de um salão palacinano. Para Pomarède (ibidem), a pintura dos trajes é particularmente detalhada e refinada, e seu 'exagero' lembra o espectador da magnitude do rei. Outros artistas de estúdio de Rigaud devem ter trabalhado em algumas partes da pintura, mas o rosto do rei - pintado em papel e montado sobre a tela - foi obra do próprio Rigaud, que produziu um retrato realista, ainda que preservando a nobreza do retratado.

O retrato que pode ser recebido como uma evolução dos já existentes cânones usados na construção de retratos oficiais de monarcas anteriores ${ }^{33}$ parece ter atingido um grau de aperfeiçoamento exemplar, já que passa a servir de referência para inúmeros retratos de monarcas posteriores. Entre eles, a magnífica representação de Louis XVI, executada por Antoine-François Callet em 1779 e, mesmo após a Revolução Francesa, o retrato de Napoleão I em trajes de coroação, pintado por François Gérard em 1805. Também é possível reconhecer as mesmas referências no retrato de Dom João VI, realizado por Jean-Baptiste Debret, em 1817.

Para Burke (2004, p.85), no passado, "os governantes eram vistos como imagens, como ícones. O traje, a postura, e as propriedades que os rodeavam transmitiam um senso de

\footnotetext{
${ }^{32}$ Disponível em: http://www.louvre.fr/en/oeuvre-notices/louis-xiv-1638-1715; acesso em 23 set. 2015.

${ }^{33}$ Elementos como a pose, tamanho da mão e um pé à frente, a cortina drapeada e a coluna já vinham sendo empregados, de forma menos exuberante, em retratos de seus antepassados, como, por exemplo, o de Luís XIII, já comentado neste artigo.
} 
majestade e poder, como no caso dos retratos pintados e esculpidos". O autor nos aconselha a fruir os retratos oficias como teatro - "representações públicas de um eu idealizado" (ibidem, idem).

Ainda sobre o retrato de Luís XIV (FIG. 8), Marin (1989) adverte sobre a importância dos símbolos usados na representação: cada um dos elementos dentro da pintura é uma insígnia e um símbolo, um ornamento simbólico ou um fragmento da história. $\mathrm{O}$ autor argumenta que

o retrato do rei é seu corpo. O retrato do rei é o próprio rei, mostrado com impressionante auto-evidência: ele é o rei, em virtude da aglomeração dos signos majestáticos que constituem o seu ser, que determinam sua presença e apresentam sua identidade. Sua essência, presença e identidade são diferentes daquelas que caracterizam um indivíduo (ibidem, p. 200) (34 $^{34}$

Dessa forma, Marin nos sugere receber o retrato do monarca como a própria construção de sua identidade. É o mesmo que afirmar que não se trata de uma representação, mas de uma apresentação de Luís XIV - o rei como imagem. O retrato construindo e constituindo o monarca.

\section{Análise comparativa dos retratos de dois meninos de dez anos}

A FIG. 9 coloca, lado a lado, dois retratos de meninos: Luís I da Espanha, com dez anos de idade, e um menino norte-americano, não identificado e, possivelmente, com a mesma idade do príncipe. O primeiro deles veste o formoso traje de noviço da Ordem da Cavalaria do Espírito Santo (de acordo com a moda francesa levada da França, pelos Bourbon - ascendentes do retratado. Tanto a posição dos pés, como a mão na cintura e a espada ao lado do quadril seguem a tradição, como já visto neste texto. O jovem posa em uma sala coberta por um tapete(?) quadriculado, e tem, ao seu lado, uma cortina amarrada por um cordão finalizado em um pingente e que repousa sobre uma cadeira. Em sua mão direita, um chapéu emplumado. A segunda criança posa em um estúdio que, assim como a sala do príncipe, também tem o piso (ou tapete) quadriculado. Ao lado do modelo, assim como no primeiro retrato, também

\footnotetext{
${ }^{34}$ Livre tradução deste autor.
} 
foi colocada uma cortina amarrada, que cai sobre uma cadeira. Uma de suas mãos se apoia sobre o espaldar da cadeira ${ }^{35}$, a outra segura um chapéu. Imediatamente atrás do menino, se vê um apoio de corpo.
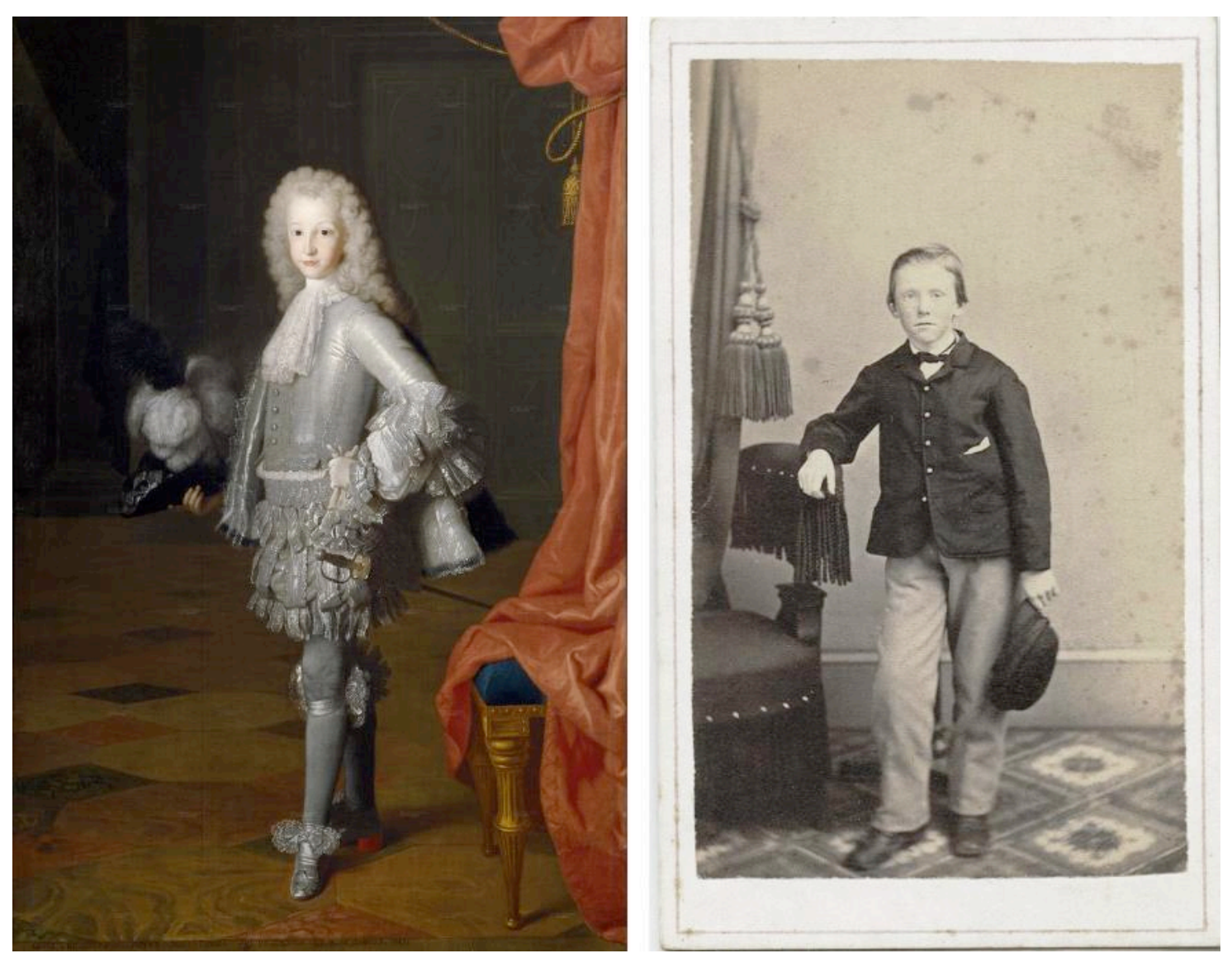

Figura 5: (imagem da esquerda) Michel Ange Houasse. Luis I, príncipe de Asturias, óleo s/tela, $172 \times 112 \mathrm{~cm}$, $1717^{36}$. (imagem da direita): Frank Edsall. Carte de visite de menino não identificado, Goshen, N.Y., c. $1860^{37}$.

Se no primeiro retrato, a sensação de amplitude é reforçada pelo jogo de chiaroscuro, no segundo, a sensação de profundidade é mínima, em função do espaço reduzido e da iluminação uniforme e difusa. Ao contrário do que se pode pensar, a parede ao fundo do retrato da criança não identificada não está manchada - os pontos escuros na superfície clara são resul-

\footnotetext{
${ }^{35}$ Trata-se de uma cadeira específica para uso em estúdios, com regulagem de altura do encosto.

${ }^{36}$ Acervo: Museu Nacional del Prado. Fonte da imagem:

https://www.museodelprado.es/educacion/educacion-propone/aniversarios-y-conmemoraciones/2007/300anos-del-nacimiento-del-rey-luis-i/; acesso em: 28 ago. 2015.

${ }^{37}$ Coleção XXXXX.
} 
tantes da ação de fungos sobre a emulsão fotográfica. Apesar dos evidentes contrastes, ambos posam ao lado da cadeira (possível símbolo do trono), da cortina (símbolo de separação, usado para delimitar o espaço cênico, distinguindo-o da plateia) e, provavelmente, vestem suas melhores roupas. Ambos estão posando.

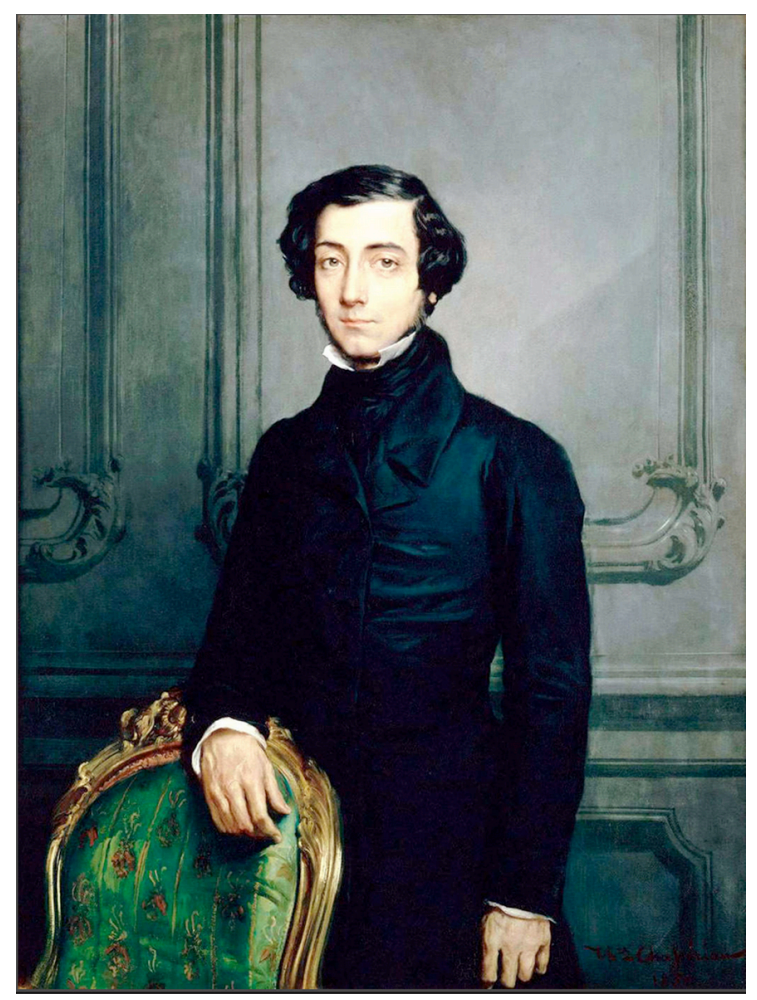

Figura 10: Théodore Chasseriau. Retrato de Alexis de Tocqueville. Óleo s/ tela, 163 x $160 \mathrm{~cm}, 1850{ }^{38}$

A mão apoiada sobre o espaldar de uma cadeira - solução tão usada em retratos dos cartões fotográficos (vide FIG. 10) - mesmo que possa ser funcional (auxilia o modelo a permanecer imóvel), tem sua origem na retratística pictórica. O retrato de Alexis de Tocqueville, visconde de Tocqueville, pensador político, historiador e escritor francês (FIG. 12), é um exemplo de pintura realizada na mesma década em que surgem os cartes de visite. A pintura representa o visconde em plano americano, com a mão direita apoiada sobre o espaldar de uma cadeira em estilo Luís XV, estofada em tecido (seda?) de estampa floral, de fundo verde.

\footnotetext{
38 Acervo do Musée National du Château de Versailles. Fonte da imagem: http://www.histoireimage.org/site/oeuvre/analyse.php?i=889; acesso em: 08 out. 2015.
} 
O traje austero é o mesmo visto em retratos fotográficos do mesmo período. A parede ornamentada com frisos que formam retângulos de cantos arredondados e decorados com folhas retorcidas também pode ser vista, representada em telões usados como fundo de alguns cartes de visite.

\section{Análise comparativa dos retratos de duas princesas e de um plebeo}

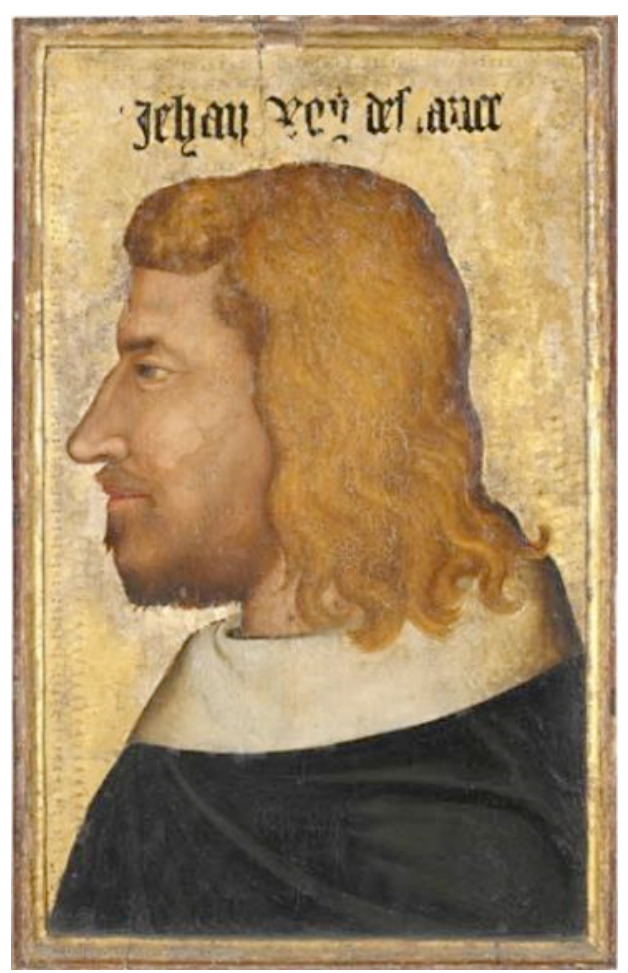

Figura 11: Autor desconhecido. Retrato de Jean Le Bon, $59.8 \times 44.6 \mathrm{~cm}$, Circa 1350. ${ }^{39}$

Em seu retrato, o rei é representado de perfil, isolado de qualquer contexto, mostrando apenas o busto do modelo, como nas antigas moedas romanas - padrão amplamente usado em retratos italianos produzidos nos séculos XV e XVI. De acordo com Castelnuovo (2006, p.23), o Retrato de Jean Le Bon - rei de França (FIG. 11) "teria sido o primeiro retrato autô-

\footnotetext{
${ }^{39}$ Acervo do Museu do Louvre. Fonte: http://www.louvre.fr/oeuvre-notices/jean-ii-le-bon-roi-de-france-13191364; acesso em: 22 set. 2015.
} 
nomo da pintura europeia, a primeira reprodução dos traços de um personagem não como doador ou simples participante numa cena mais ampla, mas isoladamente, por si mesmo".

Uma diferença fundamental entre o retrato de Le Bon e os italianos mencionados acima é a inserção da paisagem, como fundo dos retratos. Isso para não dizer do nível de realismo alcançado pelos retratos italianos. Já em determinados retratos de estúdio oitocentistas, a paisagem é lograda através do simulacro - painéis (ou telões, como também costumam ser chamados) pintados. Esses painéis costumavam representar vários temas, sendo que um dos mais frequentes era a paisagem.
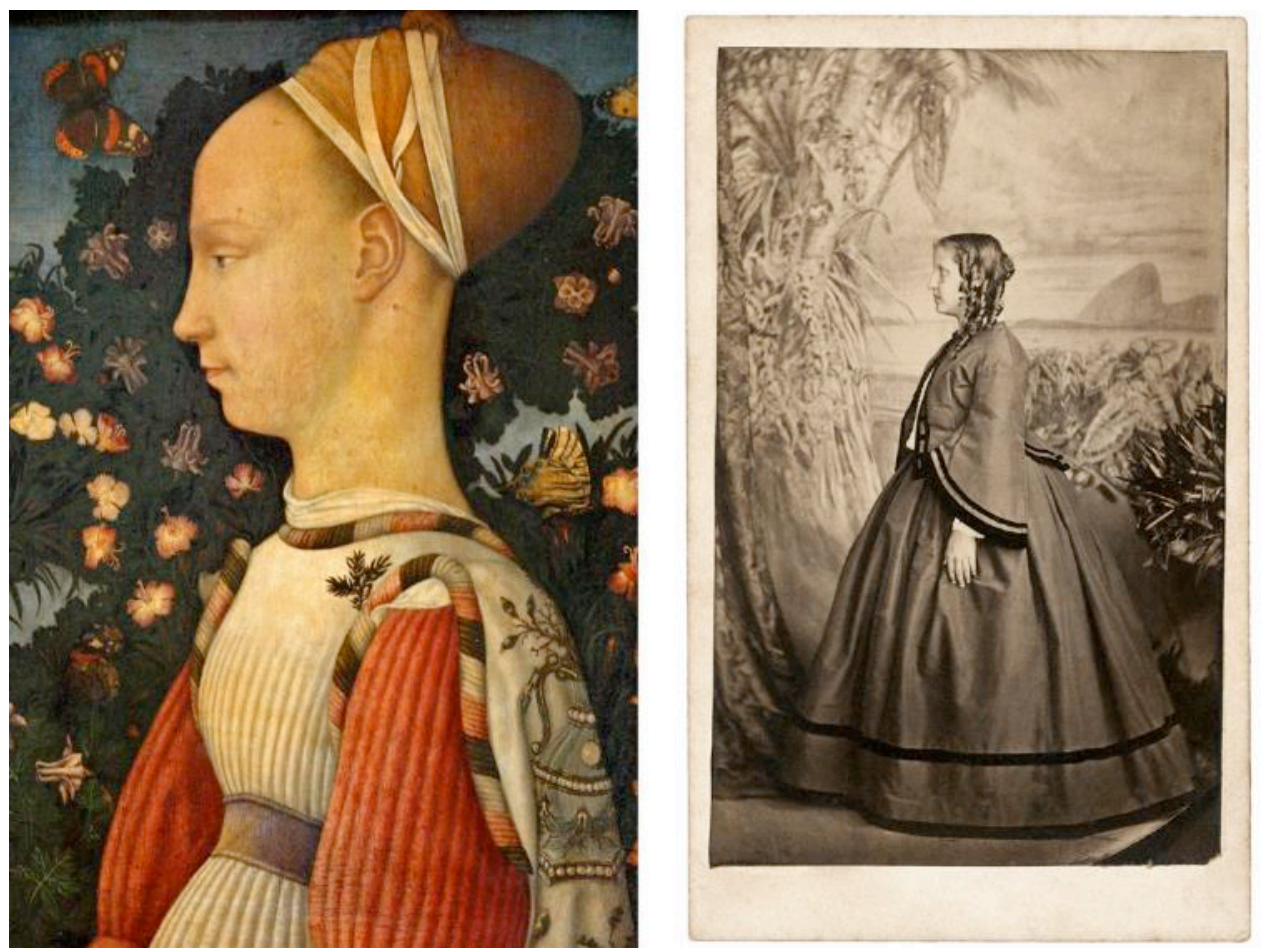

Figura 6: (esquerda) Pisanello. Retrato de uma princesa da casa de Este, Tempera s/ madeira, $43 \times 30 \mathrm{~cm}$, 1436-38. $^{40}$ (direita) Revert Henrique Klumb. CDV da princesa Isabel menina, Rio, $1863^{41}$

A princesa retratada por Pisanello (FIG. 12, esquerda) segue a tradição dos retratos de perfil usados, em moedas, desde a antiguidade. A figura - muito bem composta - é pintada com o rigor característico dos retratos italianos do período, e nota-se certa estilização das

\footnotetext{
${ }^{40}$ Acervo Museu do Louvre. Disponível em http://www.wga.hu/index1.html; acesso em: 21 set. 2015.

${ }^{41}$ Coleção Dom João De Orleans E Bragança, IMS. Fonte da imagem: Cortesia do IMS.
} 
formas do modelo e dos trajes. O fundo, concebido de forma estilizada e sintética, representa folhagens, flores e borboletas dispostas contra o azul do céu.

O carte de visite da princesa Isabel (FIG. 12, direita) mostra-se muito raro, se comparado com o significativo número de CVDs pesquisados, dentre os quais, só pode ser visto outro similar. Ele é raro por mostrar uma figura de corpo inteiro, sendo que tanto a cabeça, como o restante do corpo são apresentados de perfil. A paisagem não seria incomum, caso não representasse uma vegetação tropical, tendo ao fundo o icônico Pão de Açúcar. Se a jovem não contempla a paisagem retratada e, nem sequer, encara o olhar do espectador, em que 'direção' ela estaria olhando? Esse retrato de Isabel pode ser recebido como uma atualização (e por que não dizer tropicalização?) da tradição da retratística italiana clássica. Ele também pode ser considerado como uma adequação, ao contexto brasileiro, dos padrões inicialmente adotados pelos franceses na concepção dos CVDs.

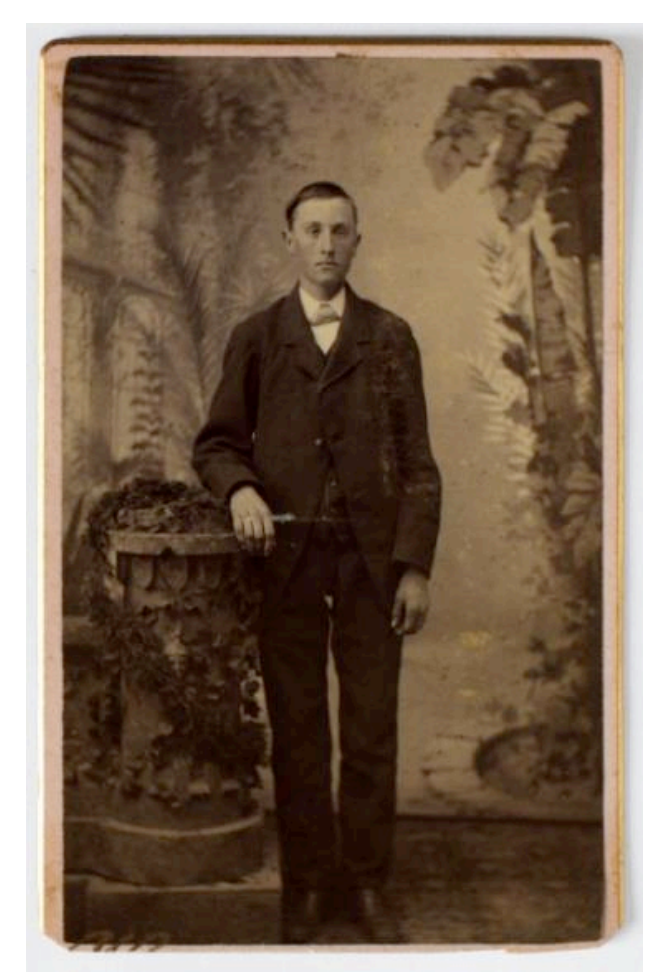

Figura 13: S. W. Howard. CDV de jovem não identificado, Kansas, c. $1870^{42}$

\footnotetext{
${ }^{42}$ Coleção XXXXX.
} 
Assim como a princesa Isabel, o rapaz não identificado (FIG. 13) é representado de corpo inteiro e em frente a um telão representativo de uma paisagem; mas há uma diferença fundamental entre os dois - ele está apoiado em um pedestal ornamentado e ela, além de estar de perfil, sustenta o próprio corpo no espaço. Além disso, ele 'dialoga' com o espectador, enquanto ela mira o que está fora do espaço da representação. De qualquer forma, ambos descendem da tradição pictórica.

\section{Mais algumas evidências da influência pictórica sobre a concepção dos retratos foto- gráficos oitocentistas}

A maioria absoluta dos retratos usados na montagem dos CVDs, pesquisados até o momento, foi produzida em estúdios fotográficos, de forma mais ou menos elaborada e usando mais ou menos objetos cênicos - desde uma simples cadeira, a cenários que envolvem coluna, mesa, cortina, fundo pintado, estátuas, etc. -, dependendo do desejo do retratado e da infraestrutura do estúdio. Entretanto, nem tudo o que é apresentado nos cartões corresponde ao que cenário em que o modelo posou. Um exemplo de edição radical da imagem é apontado por Hamilton e Ostendorf (1963). Os autores mencionam o caso do último retrato (FIG. 14) do presidente Lincoln junto a Tad, seu filho, realizado por Alexander Gardner em 1865.

Segundo Hamilton e Ostendorf (1963, p. 110), "o fundo bucólico [sylvan] neste retrato de Lincoln e Tad (FIG. 14, direita) foi adicionado para criar efeito artístico. Tanto o original (esquerda), como a versão ornamentada (direita) foram vendidos por Gardner". ${ }^{43}$ Para os autores (ibidem), outros retratos do presidente, produzidos pelo fotógrafo nesse mesmo período foram adornados com fundos barrocos. Certamente, Gardner quis se aproveitar da popularidade da figura do recém-falecido presidente e disponibilizar, no mercado, uma imagem mais atraente (plástica) e, consequentemente, mais comercial. Para isso, o fotógrafo aplicou um fundo, contendo elementos característicos da retratística clássica.

\footnotetext{
${ }^{43}$ Livre tradução deste autor.
} 

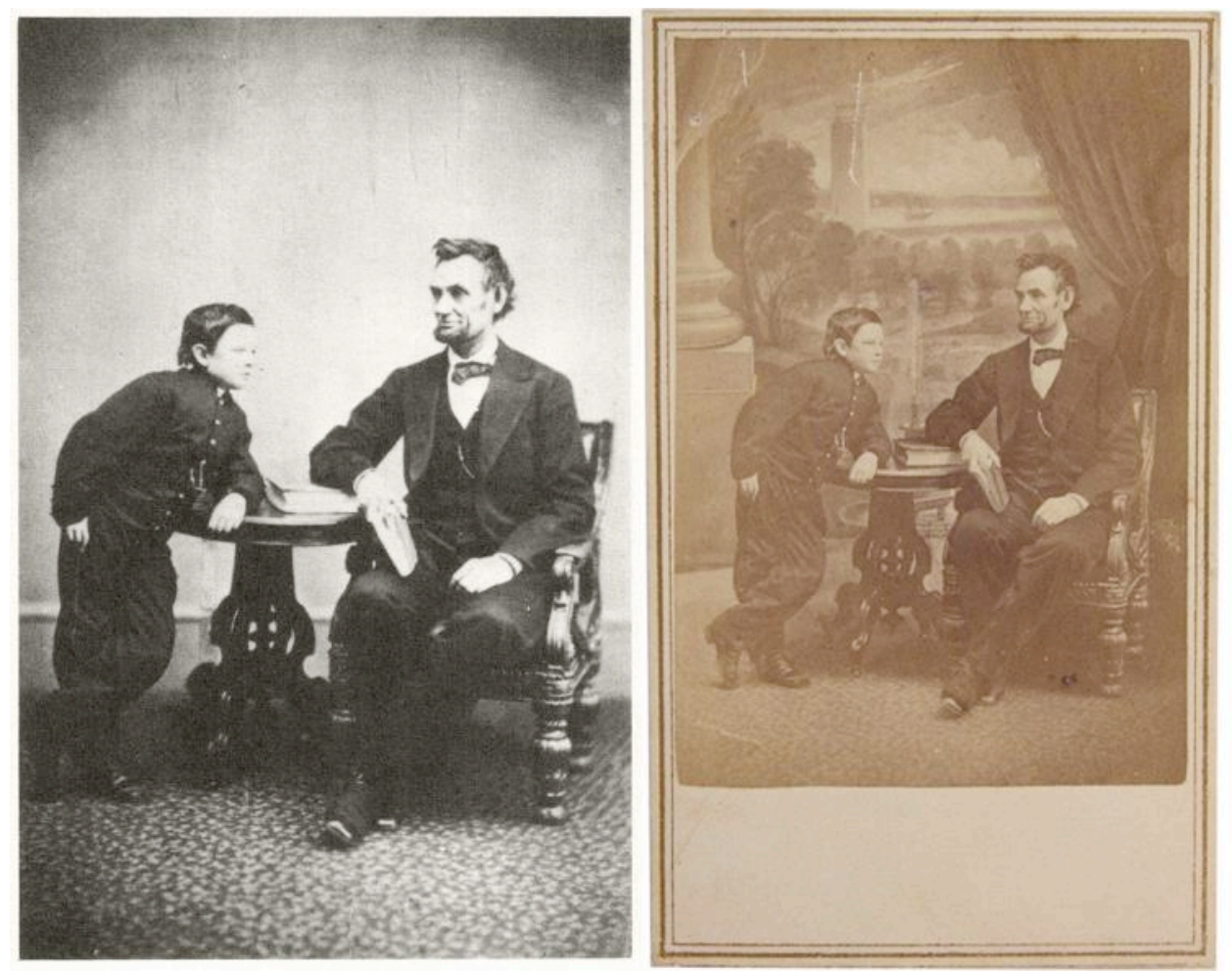

Figura 7: Alexander Gardner. Duas versões do retrato do presidente Lincoln e seu filho, Thaddeus, 1865. (esquerda) $\mathrm{O}$ retrato como foi tirado ${ }^{44}$. (direita) $\mathrm{O}$ retrato (CVD) com o fundo adicionado posteriormen$t^{45}$.

Há de se ter em conta que o retrato de Lincoln com seu filho se tornaria objeto de desejo de muitos e que, por isso, valeria o enorme trabalho de se aplicar um fundo sobre a imagem, em uma época em que tal tarefa demandava muita habilidade, perícia e trabalho manual. O mesmo tipo de montagem deve ter sido evitado na maioria dos casos.

Encerrando a série de argumentos, apresento duas imagens - versos de cartões fotográficos - (FIG. 15) que dizem, de forma explícita, do anseio de 'elevar' a fotografia ao patamar da pintura. No cartão da esquerda, a logo do estúdio é apresentada em forma de uma paleta (de pintura) adornada por ramagens floridas e equipada por alguns pincéis; sendo que, na superfície da paleta é representado um fotógrafo em ação, diante de uma paisagem alpina. Nele, o artista se apresenta: "Artista, fotógrafo de retratos e paisagens" - o que não soaria como um contrassenso, caso a informação não viesse ao lado de uma paleta e pincéis. A logo

\footnotetext{
${ }^{44}$ Coleção Ostendorf, Lincoln Financial Foundation Collection / Allen County Public Library. Fonte da imagem: HAMILTON, Charles e OSTENDORF, Lloyd (1963).

${ }^{45}$ Fonte da imagem: https://www.pinterest.com/pin/389350330256866711/; acesso em: 12 set. 2015.
} 
ilustrativa do cartão da direita segue o mesmo raciocínio do primeiro, sendo que, neste caso, a figura do fotógrafo munido de sua câmera não é representado. A "fotografia artística" de Ludwig Schill anuncia a sua "bem-sucedida" especialidade: "retratos instantâneos de crianças", como se fosse possível produzir fotografias instantâneas em 1890... Sobre a anotação "Ida Rissland - 1890", está claro que a caligrafia usada não é característica do século XIX, no entanto, não questiono a data mencionada e penso que a informação possa ter sido transcrita da página de álbum de onde o retrato foi removido.

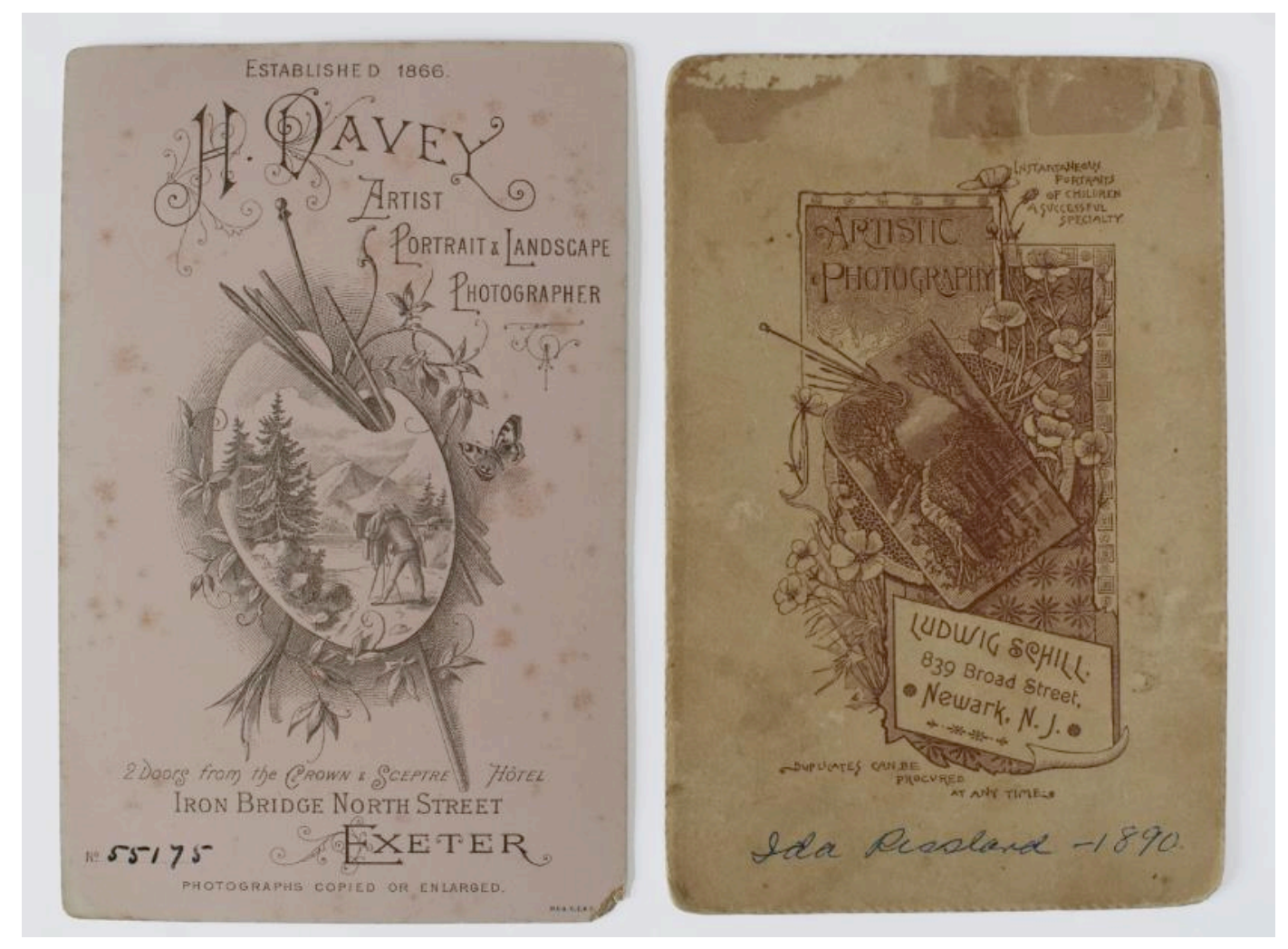

Figura 8: (esquerda) Verso de cabinet card de autoria de H. Davey, Inglaterra, sem data. (direita) Verso de Cabinet card de Ida Rissland, realizado pelo estúdio Ludwig Schill, EUA, 1890. ${ }^{46}$

Enfim, as informações contidas nas imagens da FIG. 15 constituem mais uma evidência da inclinação dos fotógrafos retratistas do século XIX em referenciar o universo pictórico, confirmando, assim, nossa hipótese.

\footnotetext{
${ }^{46}$ Ambos os cartões integram a coleção XXXXX.
} 
Cadernos Benjaminianos, Belo Horizonte, v. 11, p. 94-122

\section{REFERÊNCIAS BIBLIOGRÁFICAS}

ANDRADE, Joaquim Marçal Ferreira de. História da fotorreportagem no Brasil. Rio de janeiro: Elsevier, 2004.

BENJAMIN, Walter. Pequena História da Fotografia. In: BENJAMIN, Walter. Magia e técnica, arte e política. Obras Escolhidas I. São Paulo: Brasiliense, 1985.

BURKE, Peter. Testemunha ocular: História e imagem. Bauru, SP: EDUSC, 2004.

CASTELNUOVO, Enrico. Retrato e sociedade na arte italiana. São Paulo: Companhia das Letras, 2006.

CLARK, Gary W.. 19th Century Card Photos KwikGuide: A Step-by-Step Guide to Identifying and Dating Cartes de Visite and Cabinet Cards. Carlsbad, California: PhotoTree, 2013.

FABRIS, Annateresa. Identidades Virtuais: Uma leitura do retrato fotográfico. Belo Horizonte: Editora UFMG, 2004.

HAMILTON, Charles e OSTENDORF, Lloyd. Lincoln in photographs: an album of every know pose. Washington: Library of Congress, 1963.

KOUTSOUKOS, Sandra Sofia Machado. Negros no estúdio fotográfico. Campinas: Editora Unicamp, 2010.

MARIN, Loius. Food for thouth. Baltimore e Londres: The Hopkins University Press, 1989.

MENDES, Ricardo. Descobrindo a fotografia nos manuais: América (1840-1880) in: FRABRIS, Annateresa. Fotografia: usos e funções no século XIX. São Paulo: Editora da Universidade de São Paulo, 1998.

eISSN: $2179-8478$ 
Cadernos Benjaminianos, Belo Horizonte, v. 11, p. 94-122

PAIVA, Marco Elísio. Entrevista concedida a mim. 2015.

RICOEUR, Paul. A memória, a história, o esquecimento. Campinas, SP: Editora da Unicamp, 2007. WEST, Shearer. Portraiture. Oxford: Oxford University Press: 2004.

\section{Internet}

Dicionário dos Símbolos: http://www.dicionariodesimbolos.com.br/jardim/; acesso em: 09 out. 2015.

Glossário da moda: http://glossario.usefashion.com/Verbetes.aspx?IdIndice $=3 \& I d V e r b e t e=607$; acesso em: 09 out.2015.

L'Histoire par l'image: http://www.histoire-image.org/site/oeuvre/analyse.php?i=889; acesso em: 08 out. 2015.

POMARÈDE, Vincent. Texto sobre retrato de Luís XIV. http://www.louvre.fr/en/oeuvrenotices/louis-xiv-1638-1715; acesso em 23 set. 2015.

eISSN: $2179-8478$ 